\title{
Kerusakan Lima Varietas Padi Akibat Serangan Hama Penggerek Batang di Desa Savanajaya, Kecamatan Waeapo, Kabupaten Buru
}

\author{
Damages of Five Rice Varieties Due to Stem Borer Attack in Savanajaya Village, Waeapo District, \\ Buru Regency.
}

\author{
Muhamad F. Umakamea1, John A. Patty ${ }^{2, *}$, Ria Y. Rumthe ${ }^{1}$ \\ ${ }^{1)}$ Program Studi Agroteknologi, Jurusan Budidaya Pertanian, Fakultas Pertanian, Universitas Pattimura, Jl. Ir. M. \\ Putuhena, Kampus Poka, Ambon,97233, Indonesia \\ ${ }^{2}$ Jurusan Budidaya Pertanian, Fakultas Pertanian, Universitas Pattimura, Jl. Ir. M. Putuhena, Kampus Poka, Ambon \\ 97233, Indonesia \\ "E-mail Penulis Korespondense: johnalfred_patty@ymail.com
}

\begin{abstract}
One of the obstacles in efforts to increase rice productivity is the damage caused by the attack of the rice stem borer. Annual yield loss caused this insect pests is quite high, reaching 10-30\%. The attack of stem borer has long been encountered and is a problem in rice producing areas on Buru Island, such as in Savanajaya Village. This study aimed to obtain data on the types of pests, population levels and the intensity of damage in five rice varieties due to stem borer attact and to determine the varieties that had the lowest population and damage intensity in the Saavanajaya Village, Waeapo District, Buru Regency. The method used was a survey method that focused on five varieties of rice cultivated by farmers, to obtain population data and the intensity of damage. The results showed that the type of pest that attacked the five rice varieties of IR-64 variety in Savanajaya Village was the white rice stem borer (Scirpophaga innotata), with the highest larval population (per cluster) of 1.27 individuals and the intensity of damage 5.20\%, followed by Cigeulis variety with a larval population of 1.17 individuals and damage intensity of $4.70 \%$, the Ciherang variety with a larval population of 1.07 individuals and damage intensity of was $4.25 \%$, the Mekongan variety with a larval population of 1.1 individuals and damage intensity of $4.15 \%$, and the lowest was the Membramo variety with a larval population of 1.03 larvae and damage intensity of 4.12\%. The damage intensity of at the study site, although different between varieties, could all be classified into the category of mild attack.
\end{abstract}

Key words: damage intensity, rice varieties, Savanajaya, stem borer

\section{ABSTRAK}

Salah satu kendala dalam upaya peningkatan produktivitas padi adalah kerusakan yang disebabkan oleh serangan penggerek batang padi. Kehilangan hasil setiap tahun yang disebabkan oleh serangga hama ini padi cukup tinggi, bisa mencapai $10-30 \%$. Serangan hama penggerek batang telah lama ditemui dan menjadi masalah di daerah produsen padi di Pulau Buru, seperti di Desa Savanajaya. Penelitian ini bertujuan untuk mendapatkan data jenis hama, jumlah populasi serta intensitas kerusakan pada lima varietas padi akibat serangan hama penggerek batang serta menentukan varietas yang memiliki populasi dan intensitas kerusakan terendah di Desa Savanajaya, Kecamatan Waeapo, Kabupaten Buru. Metode yang digunakan adalah survey yang difokuskan pada lima varietas padi yang diusahakan petani, untuk mendapatkan data populasi dan ntensitas kerusakan. Hasil penelitian menunjukkan bahwa jenis hama yang menyerang lima varietas padi varietas IR-64 di Desa Savanajaya adalah penggerek batang padi putih (Scirpophaga innotata), dengan populasi larva (per rumpun) tertinggi 1,27 ekor dan intensitas kerusakan 5.20\%, diikuti oleh varietas Cigeulis dengan populasi larva 1,17 ekor dan internsitas kerusakan 4.70\%, varietas Ciherang dengan populasi larva 1.07 ekor dan intensitas kerusakan 4.25\%, varietas Mekongan dengan populasi larva 1.1 ekor dan intensitas kerusakan $4.15 \%$, dan yang terendah varietas Membramo dengan populasi larva 1.03 ekor dan intensitas kerusakan $4.12 \%$. Intensitas kerusakan di lokasi penelitian, walaupun berbeda antar varietas tetapi semuanya dapat diklasifilasikan ke dalam kategori serangan ringan.

Kata kunci: intensitas kerusakan, penggerek batang, Savanajaya, varietas padi,

\section{PENDAHULUAN}

Tanaman padi (Oryza sativa L) merupakan sumber makanan pokok bagi sebagian besar penduduk Indonesia. Untuk mengatasi kebutuhan beras yang terus meningkat, maka diperlukan upaya keras dalam 
peningkatan produksi baik kualitas maupun kuantitas. Produksi padi di Indonesia tahun 2014 sebanyak 75.398 ton dalam luasan areal 14.117 ha, tahun 2015 sebanyak 79.355 ton dalam luasan areal 15.156 ha, tahun 2016 sebanyak 81,149 ton dalam luasan areal 15,712 ha, dan tahun 2017 sebanyak 83,037 ton dalam luasan areal 15,995 ha. Sedangkan produksi padi di Kabupaten Buru tahun 2014 sebanyak 23.468 ton dalam luasan areal 5.867 ha, tahun 2015 sebanyak 23.472 ton dalam luasan areal 5.868 ha, tahun 2016 sebanyak 23.480 ton dalam luasan areal 5.870 ha, tahun 2017 sebanyak 23.496 ton dalam luasan areal 5.874 ha (BPS, 2018). Produksi padi pada tahun 2018, Kabupaten Buru sebesar 61.257,58 ton, produksi beras sebesar 34.127,86 ton,tahun 2019 sebesar 47.690 ton, produksi beras sebesar 26.524,58 ton (BPS,2020).

Salah satu kendala dalam upaya peningkatan produktivitas padi adalah kerusakan yang disebabkan oleh serangan penggerek batang padi. Di Indonesia ada enam jenis, yaitu penggerek batang padi putih (Scirpophaga innotata), penggerek batang padi kuning (S. incertulas), penggerek batang padi merah jambu (Sesamia inferens), penggerek batang padi bergaris (Chilo supressalis), dan penggerek batang padi berkepala hitam (C. polychrysus) (Kalshoven, 1981). Gejala serangan pada tanaman padi fase vegetatif disebut dengan sundep dan pada fase generatif disebut beluk. Pada fase vegetatif awal jika tanaman mengalami kerusakan hingga $30 \%$ tidak akan menyebabkan kehilangan hasil, terutama bagi varietas yang mampu membentuk anakan banyak selama fase vegetatif dan selanjutnya menjadi anakan produktif. Kehilangan hasil setiap tahun yang disebabkan oleh penggerek batang padi dapat mencapai $10-30 \%$ bahkan dapat menyebabkan tanaman padi menjadi puso (Idris, 2008).

Penggerek batang padi merupakan hama utama tanaman padi, termasuk ordo Lepidoptera dari famili Noctuidae dan Pyralidae. Serangga ini umumnya tertarik dengan lampu pada malam hari, berbentuk kupu-kupu kecil yang disebut "ngengat" dan tersebar di daratan Asia, Amerika, dan Australia. Di lahan pasang surut, hama ini selalu hadir setiap musim dengan intensitas serangan kurang dari 15 persen, tetapi bila lingkungan mendukung intensitas serangan dapat melebihi 15\% (Asikin et al., 2000).

Selama ini petani di Desa Savanajaya, Kecamatan Waeapo, Kabupaten Buru, telah melakukan pengendalian hama dengan penyemprotan insektisida sintetik, namun belum diketahui dengan jelas berapa besar jumlah populasi dan intensitas kerusakan hama penggerek batang padi. Di Desa Savanajaya terdapat gejala serangan hama penggerek yang sama, yaitu pada fase vegetatif yang disebut sundep (deadhearts) dengan gejala titik tumbuh tanaman muda mati. Gejala serangan penggerek pada fase generatif disebut beluk (whiteheads) dengan gejala malai mati dengan bulir hampa yang kelihatan berwarna putih. Gejala sundep sudah kelihatan sejak empat hari setelah larva penggerek masuk. Larva penggerek selalu keluar masuk batang padi, sehingga satu ekor larva sampai menjadi ngengat dapat menghabiskan 6-15 batang padi. Hama penggerek batang padi kuning memakan bagian dalam batang padi (Bandong and Litsinger 2005), sehingga hama ini sering menimbulkan kegagalan panen.

Berdasarkan permasalahan tersebut di atas, maka perlu dilakukan penelitian tentang kerusakan lima varietas padi akibat serangan penggerek batang padi di Desa Savanajaya, Kecamatan Waeapo, Kabupaten Buru. Tujuan penelitian ini adalah untuk mendapatkan data tentang jenis hama penggerek batang padi meliputi data jumlah populasi serta intensitas kerusakan lima varietas padi akibat serangan hama penggerek batang di Desa Savanajaya, Kecamatan Waeapo, Kabupaten Buru dan menentukan varietas yang memiliki populasi dan intensitas kerusakan terendah.

\section{BAHAN DAN METODE}

\section{Waktu dan Tempat Penelitian}

Penelitian ini dilaksanakan di Desa Savanajaya, Kecamatan Waeapo, Kabupaten Buru pada Agustus sampai September 2019.

\section{Alat dan Bahan}

Alat yang digunakan dalam penelitian ini meliputi: alat tulis menulis, thermohigrometer, kertas label, kamera, kantong plastik, dan perangkap yellow trap (lem dan plastik kuning).

Bahan yang digunakan terdiri dari lima varietas padi yang ditanam petani di Desa Savanajaya, yakni varietas Ciherang, Cigeulis, Mekongga, Membramo dan IR 64.

\section{Pelaksanaan Penelitian}

Penelitian ini dilakukan pada lima varietas padi yang diusahakan petani dengan metode survey dimana pengamatan pada 10 petani sampel, masingmasing petani sampel dengan luas petak sampel $50 \mathrm{~m}$ x $50 \mathrm{~m}$. Rumpun sampel pada petak ditentukan secara diagonal, kemudian dibagi lima sub plot dengan ukuran plot $1 \times 1 \mathrm{~m}$, pengamatan dilakukan dalam sub plot sebanyak 3 rumpun padi secara acak, selanjutnya dilakukan koleksi hama penggerek batang padi yang ditemukan.

\section{Jumlah populasi}

Pengamatan populasi hama dihitung berdasarkan jumlah kelompok telur, populasi larva, pupa, dan imago hama penggerek batang yang ditemukan pada rumpun sampel. Pengamatan imago penggerek batang dilakukan dengan menggunakan perangkap kuning, yaitu modifikasi plastik berwarna kuning dengan ukuran 15 $\mathrm{cm} \times 20 \mathrm{~cm}$ yang diberi lem sebagai perekat. Larva penggerek batang dan intensitas kerusakan yang diamati pada rumpun sampel. Waktu peletakan perangkap pada pukul 17.00 (WIT) dan pengamatan pada pukul 17.00 hari berikutnya, pengamatan diulang sebanyak 3 kali. 


\section{Pengamatan intensitas kerusakan}

Untuk menentukan Intensitas Kerusakan hama penggerek batang dapat dihitung dengan menggunakan rumus yang di kemukakan oleh (Natawigena, 1982) sebagai berikut:

$$
\mathrm{IK}=\frac{\mathrm{a}}{\mathrm{b}} \times 100 \%
$$

Di mana: IK = Intensitas kerusakan (\%); $\mathrm{a}=$ Jumlah anakan yang rusak dalam rumpun sampel; $b=$ Jumlah anakan yang diamati

Untuk mengetahui besarnya kategori serangan yang ditimbulkan oleh hama penggerek batang dapat di lihat pada Tabel 1 .

Table 1. Presentase Serangan dan kategori serangan

\begin{tabular}{cl}
\hline Presentase kerusakan & Kategori \\
\hline $0 \%$ & Normal \\
$>0-25 \%$ & Ringan \\
$>25-50 \%$ & Sedang \\
$>50-75 \%$ & Berat \\
$>75 \%$ & Sangat berat \\
\hline
\end{tabular}

\section{HASIL DAN PEMBAHASAN}

\section{Keadaan Umum lokasi}

Secara Administratif lokasi penelitian terletak pada Desa Savanajaya, Kecamatan Waeapo, Kabupaten Buru, dengan luas wilayah desa 2.730 ha, panjang desa 2,4 km; terletak pada $3^{0} 30$ '05" LS dan $127^{\circ} 1^{\prime} 70$ " BT.

Desa Savanajaya beriklim tropis dengan dua musim sebagaimana berlaku di daerah lain di provinsi Maluku, yaitu musim kemarau dan musim penghujan. Kedua musim ini berlangsung kurang lebih enam bulan, musim kemarau dari bulan September sampai bulan Februari tahun berikutnya, sedangkan musim hujan dari bulan Maret sampai bulan Agustus tahun berjalan. Selama penelitian berlangsung rata-rata suhu $31,5^{\circ} \mathrm{C}$ (kisaran $26^{\circ}-45^{\circ} \mathrm{C}$ ) dan rata-rata kelembaban $64,3 \%$ (kisaran 21-89\%). Jenis tanah pada lokasi penelitian di Desa Savanajaya adalah jenis tanah aluvial (BPS, 2012).

Desa Savanajaya memiliki potensi utama tanaman pangan terutama padi yang merupakan komoditas andalan untuk mendukung ketersediaan beras di Pulau Buru, karena permintaan beras di pasaran cukup menjanjikan.

\section{Jenis Penggerek Batang Padi yang Ditemukan}

Berdasarkan hasil pengamatan di areal pertanaman selama penelitian, jenis hama penggerek batang yang di temukan adalah: hama penggerek batang padi putih (Scirpophaga innotata). Serangga hama ini mempunyai ciri-ciri: ngengat atau imago ditandai dengan sayap berwarna putih dan ukuran serangga betina $13 \mathrm{~mm}$ dan jantan $11 \mathrm{~mm}$ (Gambar 1). Sedangkan jenis penggerek batang padi kuning, penggerek batang merah jambu, penggerek batang bergaris, dan penggerek batang berkepala hitam tidak ditemukan lokasi penelitian.
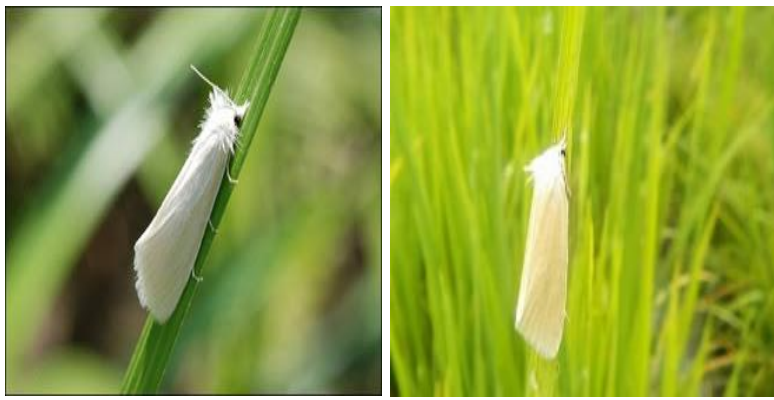

Gambar 1. Ngengat Scirpophaga innotata

Hasil penangkapan populasi imago penggerek batang padi putih dengan menggunakan yellow trap (Gambar 2) berhasil menangkap serangga hama maupun serangga lainnya. Selain imago hama penggerek batang yang tertangkap, juga terdapat predator capung dan laba-laba.

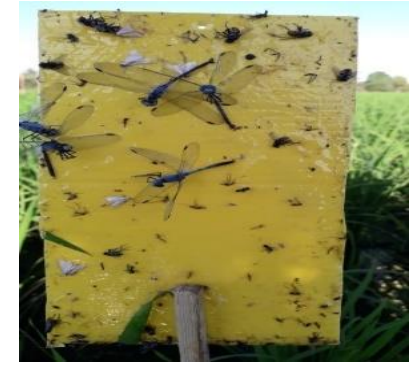

Gambar 2. Yellow trap dengan imago penggerek batang padi yang tertangkap

Ngengat penggerek batang padi putih ( $S$. innotata) meletakan telur secara berkelompok pada permukaan atas daun dan pelepah batang padi yang ditutupi rambut halus berwarna coklat kekuningkuningan, satu kelompok telur terdiri dari 170 - 260 butir (Gambar 3).

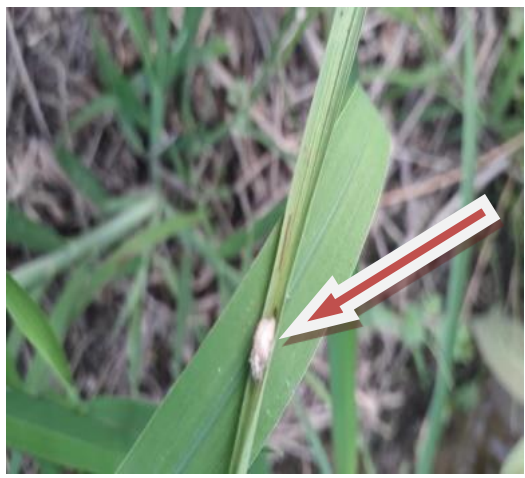

Gambar 3. Kelompok telur penggerek batang padi putih

Larva penggerek batang padi putih terdapat dalam batang padi pada tempat gerekan; berwarna putih kekuningan sampai kehijauan dengan panjang maksimal $21 \mathrm{~mm}$ (Gambar 4). 


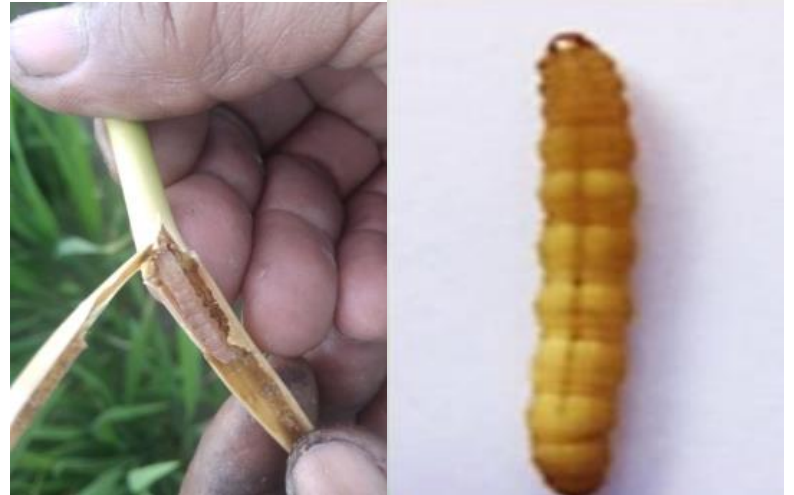

Gambar 4. Larva penggerek batang padi putih

\section{Populasi Penggerek Batang Padi Putih}

Selama pengamatan dilakukan tidak ditemukan stadia pupa; yang ditemukan hanya stadia telur, larva, dan imago. Hasil analisis data populasi telur, larva, imago dapat dilihat pada Tabel 3.

Tabel 3. Rata-rata populasi penggerek batang padi putih (S. innotata)

\begin{tabular}{lccc}
\hline \multicolumn{1}{c}{ Varietas } & Telur & Larva & Imago \\
\hline Cigeulis & 7 & 1,17 & 10 \\
Ciherang & 4 & 1,07 & 19 \\
Mekongga & 4 & 1,10 & 15 \\
IR 64 & 6 & 1,27 & 19 \\
Membramo & 7 & 1,03 & 13 \\
\hline
\end{tabular}

\section{Intensitas Kerusakan Tanaman Padi}

Pengamatan intensitas kerusakan hama penggerek batang padi putih di Desa Savanajaya menunjukan bahwa batang padi yang terserang menunjukan gejala sundep; ini dapat dilihat pada (Gambar 5).

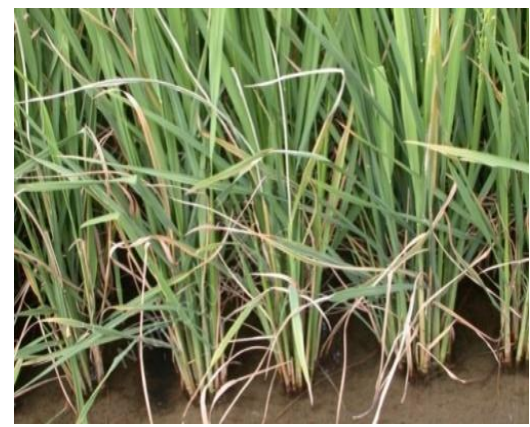

Gambar 5. Intensitas kerusakan tanaman akibat serangan hama penggerek batang padi putih

Hasil perhitungan rata-rata intensitas kerusakan tanaman padi akibat serangan hama penggerek batang padi putih pada lima varietas padi di Desa Savanajaya disajikan pada Tabel 4.
Tabel 4. Rata-rata intensitas kerusakan tanaman padi akibat serangan hama penggerek batang padi

\begin{tabular}{cc}
\hline Varietas & Intensitas Kerusakan $(\%)$ \\
\hline Membramo & 4,12 \\
Mekongga & 4,15 \\
Ciherang & 4,25 \\
Cigeulis & 4.70 \\
IR 64 & 5.20 \\
Jumlah & 22,42 \\
\hline Rata- rata & 4,48 \\
\hline
\end{tabular}

Berdasarkan data Tabel 4, didapatkan bahwa rata-rata intensitas kerusakan tanaman padi akibat serangan hama $S$. innotata di Desa Savanajaya adalah sebesar $4.48 \%$ dan tergolong kriteria kerusakan ringan. Intensitas Kerusakan tertinggi terjadi pada varietas IR $64(5,20 \%)$ dan terendah pada varietas Membramo $(4,12 \%)$

\section{Hubungan Antara Populasi Larva dengan Intensitas Serusakan}

Berdasarkan hasil pengamatan populasi larva dan intensitas kerusakan pada lima varietas padi di Desa Savanajaya, maka dibuat hubungan analisis regresi yang hasilnya sebagaimana ditunjukkan pada Gambar 6.

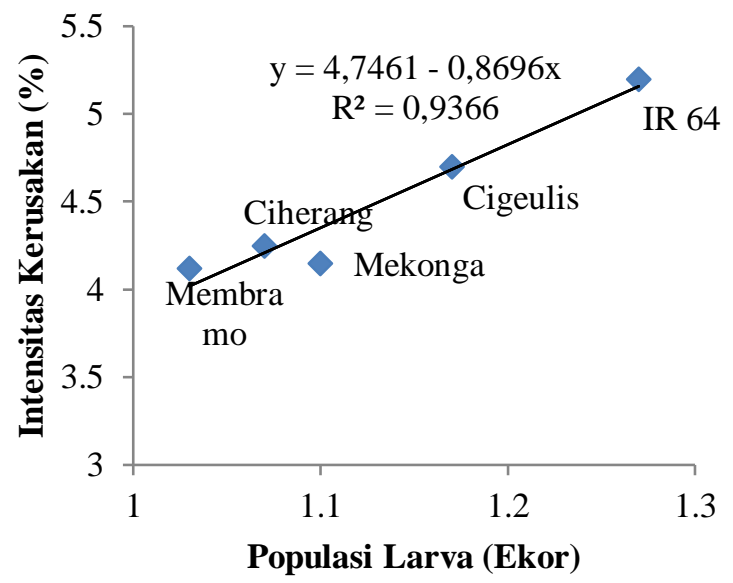

Gambar 6. Hubungan antara populasi larva dan intensitas kerusakan

\section{Pembahasan}

Petani di Desa Savanajaya dalam pembudidayaan tanaman tidak pernah mengganti jenis tanaman dengan komoditas lain selain tanaman padi. Oleh karena itu, masalah hama selalu timbul karena siklus hidup hama tidak terputus dan akan berkelanjutan. Dalam hal pengendalian hama dengan menggunakan pestisida sintetik, petani sering melakukan aplikasi berlebihan, begitu pula dengan dosis dan konsentrasinya. Hal ini dapat menyebabkan berbagai dampak negatif, seperti terbunuhnya musuh alami, hama menjadi resisten serta lingkungan juga tercemar. 
Dalam mengusahakan suatu jenis tanaman pertanian selalu timbul berbagai serangan organisme pengganggu tanaman (OPT). Apabila tidak dikendalikan dengan baik, maka resiko kegagalan akan dihadapi. Hal ini dapat dilakukan dengan berbagai teknik pengendalian yang tersedia antara lain: pengendalian secara fisik atau mekanis, kultur teknis, hayati dan kimiawi (Untung, 2006).

Bila suatu jenis hama menyerang suatu jenis tanaman, maka tanaman tersebut akan menunjukan pertumbuhan yang abnormal. Hal ini ditandai dengan gejala atau perubahan yang terjadi pada tanaman seperti hilangnya luasan daun, batang berlubang, tanaman menjadi layu dan mati, terhambatnya proses translokasi air dan unsur hara menyebabkan proses fotosintesis dan metabolisme tidak dapat berlangsung dengan baik. Dengan demikian, produksi baik secara kualitas maupun kuantitas akan menurun. Untuk mengatasi masalah serangan hama tersebut, maka berbagai upaya pengendalian harus dilakukan.

\section{Jenis hama yang ditemukan}

Data hasil penelitian pada areal pertanaman padi di Desa Savanajaya menunjukkan bahwa hanya ditemukan hama penggerek batang padi putih ( $S$. innotata) dengan ciri-ciri ngengat berwarna putih, denganpanjang tubuh 12.3-14 mm (Manueke et al., 2017). Penyebab munculnya populasi penggerek batang padi putih diduga antara lain akibat dari perubahan iklim (Estay, 2009). Fenomena kemarau panjang diPulau Buru yang terjadi selama tahun 2019, menunjukkan bahwa faktor iklim telah memicu berkurangnya populasi dan kematian jenis serangga yang lain, seperti hama wereng.

\section{Jenis predator dan parasit hama penggerek batang padi yang ditemukan}

Dari hasil pengamatan di lapangan didapati predator dan parasit yang menyerang hama penggerek batang padi; predator-presator itu meliputi capung, labalaba, semut dan jangkrik. Di ketahui bahwa predator tersebut memangsa hama penggerek batang dari telur sampai dengan imago sehingga menekan populasi hama penggerek batang padi.

Parasit telur Telenomus merupakan parasit kecil berwarna hitam yang menjadi parasit telur-telur penggerek batang padi. Parasit ini biasanya mengincar ngengat betina penggerek batang padi yang telah siap bertelur, kemudian akan hinggap di ujung perut ngengat betina dewasa dekat dengan alat untuk meletakan telur (ovipositor). Ketika ngengat betina mulai bertelur, Telenomus akan segera menitipkan telurnya dengan menyuntikan ke dalam telur-telur yang baru dikeluarkan ngengat betina. Setelah 10-14 hari, telur akan menetas dan yang keluar bukan ulat penggerek batang padi, melainkan parasit Telenomus baru. Tingkat parasit Telenomus di lapangan berkisar antara 36-90 \% (Zainudin, 2013).

\section{Populasi hama penggerek batang padi putih}

Hasil pengamatan yang dilakukan terhadap populasi hama penggerek batang padi putih menunjukkan bahwa hanya ditemukan populasi telur, larva dan imago, sedangkan pupa tidak ditremukan. Hal ini disebabkan karena saat pengamatan belum sampai stadium pupa sehingga tidak ditemukan saat pengamatan. Telur diletakkan secara berkelompok pada permukaan atas daun atau pelepah. Bentuk kelompok telur ditutupi rambut halus berwarna coklat kekuningkuningan. satu kelompok telur terdiri dari 170-260 butir dan stadium telur 4-9 hari. Kelompok telur yang ditemukan pada lima varietas padi yang diusahakan petani di Desa Savanajaya memiliki jumlah kelompok telur yang berbeda. Pada varietas Mekongga dan Ciherang jumlahnya 4 kelompok. Sedangkan pada varietas padi IR-64 dan Membramo jumlah masingmasing 6 kelompok telur dan tertinggi pada varietas Cigeluis, yaitu 7 kelompok.

Rata-rata populasi larva pada lima varietas tidak berbeda satu dengan yang lainnya Populasi larva terendah terdapat pada varietas Membramo, yakni 1,03 ekor. Hal ini disebabkan karena penggunaan insektisida yang kurang tepat dengan tidak mengikuti standar SOP dan nilai ambang ekonomi. Stadium larva berlangsung 19-31 hari, kecuali larva yang berdiapause. Pada akhir musim kemarau larva instar akhir tidak langsung menjadi pupa, tetapi mengalami diapause dalam pangkal batang atau tunggul. Hal ini biasanya terjadi di daerah tropis yang memiliki perbedaan musim hujan dan kemarau yang jelas. Lama diapause tergantung pada lamanya musim kemarau. Setelah turun hujan tanah lembab, larva yang berdiapase akan menjadi pupa.

Kehilangan hasil setiap tahun yang disebabkan oleh penggerek batang padi dapat mencapai $10-30 \%$, bahkan dapat menjadikan tanaman padi menjadi pusso (Idris, 2008). Oleh karena itu, sampai saat ini penggunaan insektisida sintetik merupakan andalan bagi petani di desa Savanajaya dalam mengendalikan hama penggerek batang padi putih. Sebagian petani juga mencampur beberapa insektisida dengan tidak cermat tanpa mempertimbangkan risiko yang ditimbulkan dan pengaplikasian insektisida sintetik secara terus menerus dengan konsentrasi yang berlebihan. Akibat penggunaan insektisida tidak bijaksana akan berdampak pada lingkungan, seperti: hama menjadi resisten, terjadi peledakan hama (resurgensi), muncul hama sekunder, terbunuhnya organisme nontarget dan residu pada tanaman. Salah satu insektisida yang digunakan adalah Dangke 40 WP dengan bahan aktif metomil $40 \%$ dengan daya bunuh ganda, yaitu bersifat racun perut dan racun lambung dan dapat menekan populasi larva penggerek batang padi putih (Direktorat Pupuk dan Pestisida, 2012). Penggunaan insektisida Dangke 40 WP dalam usaha tani padi dikarenakan daya bunuh terhadap serangga sasaran serta waktu sangat cepat. Namunsecara umum insektisida sintetik mempunyai dampak negatif terhadap konsumen, hama serta musuh alami yang sangat besar, sehingga dalam 
penggunaannya perlu diketahui nilai ambang ekonominya.

Populasi larva batang padi tertinggi pada varietas IR-64 sebesar 1,27 ekor per rumpun. Hal ini diduga disebabkan karena, petani sering mencampur beberapa insektisida untuk mengendalikan hama penggerek batang padi putih, sehingga menyebabkan tidak adanya daya racun untuk menekan populasi hama tersebut. Kurangnya informasi bagi petani tentang bagaimana cara mencampur dua jenis insektisida dalam melakukan pengendalian akan berpengaruh terhadap hasil pengendalian yang diperoleh.

Rata-rata populasi imago yang didapat dari hasil tangkapan selama penelitian adalah pada varietas Ciherang dan IR64 sebesar (19 ekor), kemudian diikuti oleh varietas Mekongga (15 ekor), varietas Membramo (13 ekor) dan terendah pada varietas Cigeulis. Faktor yang menyebabkan jumlah penagkapan imago yang berbeda adalah jarak antar lahan yang diamati sangat berdekatan satu dengan yang lain, sehingga imago penggerek batang padi putih dapat terbang dari satu lahan ke lahan yang lain. Menurut Suharto (2010) ngengat penggerek batang padi putih merupakan penerbang yang kuat, dan mampu terbang sejauh $6 \mathrm{~km}$ dalam usaha untuk meletakkan telurnya.

Petani di Desa Savanajaya juga sering melakukan pemupukan berlebihan per musim tanam dengan menggunakan pupuk urea dan NPK. Ternyata penggunaan pupuk juga mempengaruhi perkembangan larva penggerek batang. Larva penggerek lebih menyukai tanaman padi yang dipupuk dengan pupuk $\mathrm{N}$ tinggi, karena mengandung protein tinggi. Menurut Haryatun (2006), beberapa hasil penelitian menunjukkan bahwa pada tanaman yang dipupuk dengan $\mathrm{N}$ dengan dosis tinggi, maka kerusakan yang ditimbukkan oleh hama juga tinggi. Menurut Suparno (1995), tanaman padi yang dipupuk lebih banyak mengandung protein, sehingga selama pertumbuhan, larva memakan jaringan tanaman padi yang lebih banyak mengandung protein.

\section{Intensitas kerusakan tanaman padi}

Berdasarkan hasil penelitian intensitas kerusakan tanaman padi di desa Savanajaya akibat serangan penggerek batang padi putih (Scirpophaga innotata), terdapat perbedaan yang sangat rendah. Pada varietas Cigeulis $(4.70 \%)$, varietas Ciherang $(4.20 \%)$, varietas Mekonggaa (4.15 \%), varietas IR-64 (5.2 \%) dan varietas Membramo (4.12 \%). Dari hasil rata-rata intensitas kerusakan pada lima varietas yang diamati, tergolong dalam kriteria "ringan". Artinya kerusakan pada fase vegetatif akibat serangan penggerek batang padi putih masih tergolong ringan, namun dengan bertambahnya umur tanaman serangan pada fase generatif bisa menggagalkan panen apabila tidak dilakukan pengendalian dengan baik. Intensitas kerusakan yang ditimbulkan oleh hama penggerek batang sangat berhubungan erat dengan populasi larva di areal pertanaman. Fattah (2012) mengatakan bahwa intensitas kerusakan penggerek batang padi putih akan meningkat pada tanaman padi memasuki masa generative (40 hari HST) dan mengalami penurunan pada fase pemasakan (75 hari HST). Berdasarkan hal tersebut, maka untuk menghindari serangan penggerek batang padi pada fase generative, maka waktu tanam terbaik adalah tanggal 1 kalender. Hal ini akan menghindari puncak penerbangan penggerek batang padi saat bulan purnama. Sedangkan, menurut hasil penelitian Wahid (2007), intensitas serangan batang penggerek padi putih di Kabupaten Parigi, Sulawesi Tengah, pada fase vegetative dengan intensitas serangan cukup tinggi yaitu 20,66 sampai 28,99\%. Sedangkan, memasuki masa generatif sebesar 0,11 sampai $2,67 \%$.

\section{Hubungan populasi larva dengan intensitas kerusakan tanaman padi}

Stadia larva merupakan stadia perusak dari hama penggerek batang padi putih. Hal ini disebabkan karena tanaman inang dari hama tersebut adalah tanaman padi, sehingga saat muncul hamanya tersebut sesuai dengan stadia pertumbuhan tanaman padi. Gambar 6 menunjukkan bahwa semakin besar jumlah populasi larva semakin besar intensitas kerusakan yang ditimbulkan oleh hama tersebut. Hal ini sesuai dengan Damayanti et al. (2015). Lima varietas padi yang ditanam oleh petani di Desa Savanajaya, ternyata varietas IR 64 dengan intensitas tertinggi, yaitu 5.20\% dengan populasi larva 1,27 ekor per rumpun. Umur tanaman padi saat pengamatan berkisar antara 58-60 hari setelah tanam, sedangkan umur panen dari varietas yang diusahan berkisar antara 81-125 hari. Dengan demikian dengan bertambahnya umur tanaman, merupakan kesempatan bagi hama untuk melakukan kerusakan semakin bersar. Hal ini sesuai dengan yang sebelumnya dikemukakan oleh Badan Ketahanan Pangan NAD (2009), serangan hama penggerek batang padi putih semakin besar mulai dari pesemaian (masa vegetatif) sampai fase generatif (pembentukan bunga dan pengisian bulir).

Apabila terhadap pertanaman padi yang sudah terserang hama penggerek batang padi putih tidak dilakukan pengendalian, akan terserang semakin berat bahkan dapat mengalami gagal panen.

\section{KESIMPULAN}

Berdasarkan hasil penelitian dan pembahasan, maka dapat disimpulkan bahwa: jenis hama yang menyerang lima varietas padi varietas IR-64 di Desa Savanajaya adalah penggerek batang padi putih (Scirpophaga innotata), dengan populasi larva (per rumpun) tertinggi 1,27 ekor dan intensitas kerusakan $5.20 \%$, diikuti oleh varietas Cigeulis dengan populasi larva 1,17 ekor dan internsitas kerusakan $4.70 \%$, varietas Ciherang dengan populasi larva 1.07 ekor dan intensitas kerusakan $4.25 \%$, varietas Mekongan dengan populasi larva 1.1 ekor dan intensitas kerusakan $4.15 \%$, dan yang terendah varietas Membramo dengan populasi larva 1.03 ekor dan intensitas kerusakan $4.12 \%$. 
Intensitas kerusakan walaupun berbeda antar varietas, tetapi semuanya masuk dalam kartegori serangan ringan

\section{DAFTAR PUSTAKA}

Asikin, S., M. Thamrin, dan N. Djahab. 2000. Pemanfaatan purun tikus dalam pengendalian hama penggerek batang padi putih di lahan sulfat masam. Berita Puslitbangtan No. 17. Puslitbangtan Bogor.

Badan Ketahanan Pangan NAD. 2009. Pedoman Rekomendasi Pengendalian Hama Terpadu pada Tanaman Padi. p.46-57. Direktorat Perlindungan Tanaman, Direktorat Jenderal Bina Produksi Tanaman Pangan, Departemen Pertanian. Jakarta.

Badan Pusat Statistik (BPS). 2018. Produksi, Luas Panen dan Produktivitas Padi di Indonesia. Badan Pusat Statistik, Jakarta

Bandong, J.P. and J.A. Litsinger. 2005. Rice crop stage susceptibility to the rice yellow stemborer Scirpophaga incertulas (Walker) (Lepidoptera: Pyralidae). International Journal of Pest Management 51:37-43. DOI: 10.1080/09670870400028276.

Damayanti, E., G. Mudjiono, dan S. Karinda. 2015. Perkembangan populasi larva penggerek batang dan musuh alaminya pada tanaman padi (Oryza sativa L.). Jurnal HPT 3(2): 18-24.

Direktorat Pupuk dan Pestisida (DPP). 2012. Data Luas Serangan Penggerek Batang Padi 2005-2012. Jakarta: DPP, Direktorat Pupuk dan Pestisida, Jakarta.

Estay, S.A., M. Lima, F.A. Labra. 2009. Predicting insect pest status under climate change scenarios: combining experimental data and population dynamics modelling. Journal of Applied Entomology 133(7): 491-499. DOI: 10.1111/j.1439-0418.2008.01380.x.

Fattah, 2012. Tingkat Serangan Hama Penggerek Batang Padi Putih (Schirpophaga innotata, S. incertulas, Chilo supresalis dan Sesamia inferens) di Sulawesi Selatan. Prosiding Seminar
Nasional Hasil Penelitian Padi 2011. Inovasi Teknologi. Balai Besar Penelitian Tanaman Padi (BBPadi), Subang.

Haryatun. 2006. Pengendalian Hama Penggerek Batang Padi Putih dengan Cara Tanam dan Pemberian Abu Sekam di Lahan Pasang Surut, p.327-331. Pusat Penelitian dan Pengembangan Peternakan. Kalimantan Selatan.

Idris. 2008. Fluktuasi Populasi Spesies Penggerek Batang Padi di Kabupaten Konawe. p.1- 5. Balai Pengkajian Teknologi Pertanian (BPTP) Sulawesi Tenggara.

Kalshoven, L. G. E. 1981. The Pests of Crops in Indonesia. Revised and Translated by P. A. Van Der Laan, University of Amsterdam with the Assistance of G. H. L. Rothschild, CSIRO, Canberra. P.T. Ichtiar Baru Van Hoeve. Jakarta.

Manueke, J., B. H. Assa, E. A. Pelealu. 2017. Hamahama pada tanaman padi sawah di Kelurahan Makalonsow Kecamatan Tondano Timur Kabupaten Munahasa. Eugenia 23(3): 120-127. DOI: 10.35791/eug.23.3.2017. 18964.

Natawigena, 1982. Pestisida dan Kegunaannya. Penerbit CV. Armico. Bandung.

Suparno, T. 1995. Pertumbuhan dan Perkembangan Scirpophaga innotata Walker (Lepidoptera: Pyralidae) pada Tanaman Padi di Tanah dengan Kandungan Kalium Berbeda. Disertasi. Institute Pertanian Bogor, Bogor.

Untung, 2006. Kebijakan Perlindungan Tanaman. Gadjah Mada University Press. Yogyakarta.

Wahid, A, 2007. Ketahanan Empat Varietas Padi (Oryza sativa Linn) terhadap Serangan Penggerek Batang Padi Putih S. innotata (Lepidoptera, Pyralidae). Agroland, Jurnal Ilmu-Ilmu Pertanian 18(2): 92-96.

Zainudin, 2013. Mengenal musuh alami penggerek batang padi. Balai Penelitian Pertanian Lahan Rawa, Banjarbaru. http://balittra.litbang. pertanian.go.id/index.php/publikasi/buku/69publikasi/artikel-ilmiah/1720-mengenal-musuhalami-penggerek-batang-padi. 